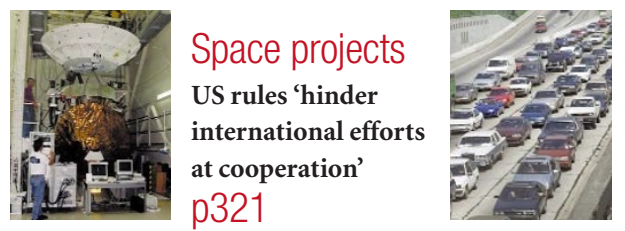

Automakers out
General Motors
leaves anti-Kyoto
lobby group
p322

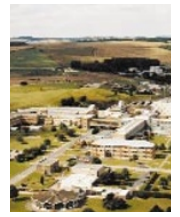
Synchrotron site Daresbury loses out to the south in UK location controversy p323

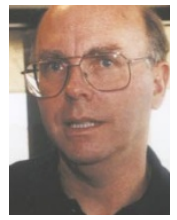
Genome data Celera reveals the terms of access to its data bank p324

\title{
Researchers caught in dispute over transgenic mice patents
}

\section{San Diego}

Neuroscientists who use mouse models are closely watching a patent infringement battle between a prominent biotechnology firm and a major US non-profit institution.

Elan Pharmaceuticals, of Ireland, is suing the Minnesota-based Mayo Foundation for Medical Education and Research over mice used to study Alzheimer's disease. The company alleges that Mayo has infringed two patents it holds on transgenic mice with a mutation that causes Alzheimer's.

Elan uses its closely guarded mice for work on potential drugs against the neurodegenerative disease. The company alleges that Mayo is infringing its patents by making, using, and selling mice that overexpress an Alzheimer amyloid precursor protein, APP695, from a human genetic mutation. Mayo says it has licences from patent holders for both the mutation and the mice, which it distributes to researchers worldwide. A jury is due to decide the issue in October.

According to documents filed with the US District Court in San Francisco, Mayo is making the counterclaim that the Elan patents were obtained fraudulently from the US Patent and Trademark Office and that they are unenforceable and therefore invalid. Mayo attorney Karen Boyd would not specify the grounds for such allegations.

The battle is spreading unease among US neuroscientists because some are being subpoenaed - along with their laboratory notebooks - to testify in depositions for the civil lawsuit quietly filed by Elan last April.

"It is outrageous," says Karen Duff, a New York University neuroscientist who has been subpoenaed by Elan. After receiving her doctorate at Imperial College London, Duff once worked at Mayo's research facility in Jacksonville, Florida, and has used the Mayo mouse model to create another transgenic mouse that is considered extremely important for research.

The dispute is seen by neuroscientists as complicating an already difficult research arena, in which the number of animal models for unravelling the biological secrets of the disease is already limited.

"All of this does no one any good," says
John Trojanowski, a physician with a doctorate in neuroscience who directs a National Institute of Aging (NIA) Alzheimer Center at the University of Pennsylvania. "The Alzheimer research field could move considerably faster" without the lawsuit, he argues.

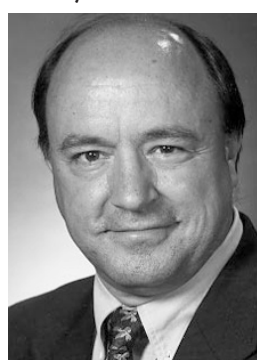

Younkin: licensing agreement necessary. solving their dispute out of court, Elan filed its lawsuit a few months later.

Elan attorney Jean Duvall says that no one at the firm's Dublin headquarters will comment except to say "it is Elan's policy to enforce its intellectual property rights".

The Elan-Mayo lawsuit is so sensitive that Marcelle Morrison-Bogorad, NIA's associate director for neuroscience and neuropsychology, cancelled a scheduled interview on the subject last week — shortly after the joint statement by President Bill Clinton and British Prime Minister Tony Blair on the need for open access to genetic data (see page 324).

"It is critically important that research tools are available to scientists," MorrisonBogorad says. "We are looking into the current controversy over research resources for Alzheimer's disease and evaluating its impact on the field, on initiatives in the private sector and on the overall progress of research."

The Elan-Mayo legal dispute involves a number of patent, licensing and research agreements with both proprietary and academic institutions. The two patents Elan alleges are being infringed are owned jointly by the firm and Eli Lilly \& Co.

Elan secured rights to the patents in 1998, after acquiring Athena Neurosciences, a firm that had licensed research findings from academic institutions and companies.

The two Elan patents are for "transgenic ... rodents" that harbour an allele for the 'Swedish mutation' — named after a large

\section{Iridium crash relieves astronomers}

Munich

Radioastronomers may not be gloating publicly over the final plunge of the global mobile telephone company Iridium into bankruptcy last week. But news that the company's 66 satellites must be brought out of orbit and burnt up in the atmosphere as part of the bankruptcy agreement has ignited a private outbreak of schadenfreude.

Radioastronomers have been fighting for years against the satellite system developed by Iridium, which was allocated a waveband right beside the $1612 \mathrm{MHz}$ band reserved for astronomical observations. Despite assurances, Iridium refused to cap the use of its satellites at a level that would avoid 'overspill' into the radioastronomy band, drowning out weak radio signals from space.
Last year, European radioastronomers reached a compromise with Iridium under which the company was required to guarantee some hours of 'quiet time' over radio observatories (Nature 399, 513; 1999). But since their launch in November 1998, the 66 brightly reflecting satellites have also interfered with optical observations from ground-based telescopes.

"We have learnt from the affair that promises made at one time are not always kept," says Willem Baan, director of the Westerbork Observatory in northern Holland and one of the fiercest opponents of Iridium. Been is now working to ensure that, in future, frequencies reserved for science are protected from unexpected commercial encroachment. 
Scandinavian family in which it was identified - that is believed to contribute to Alzheimer's disease by producing a build-up of amyloid plaque in the brain.

Researchers say that Elan transgenic mice are closely held by the firm for its drug development efforts. One researcher alleges that when Elan mice are provided to academic scientists, they are usually neutered females.

Mayo's transgenic mice, provided to more than 50 academic research groups and a dozen pharmaceutical firms, are based on work by a group headed by Karen Hsiao at the University of Minnesota.

Hsiao's group created a mouse that would express amyloid in the brain (see Science 274, 99-103; 1996). After publication, Mayo licensed the discovery from the University of Minnesota, arranged for contract breeding of the mice and began distributing them. Mayo also licensed the sequence of the Swedish mutation from a Kansas firm.

Mayo's mice are considered so valuable that there are reports of breeding trios of males being sold to companies for $\$ 850,000$. Mayo officials decline to discuss this.

When providing its mice to academic institutions, Mayo requires the signing of a material transfer agreement that gives the non-profit organization an option to buy the rights to any commercial discovery that may come from research with the mice.

This agreement - like those used by biotech firms - is considered by some to be an unusually bold move for a non-profit organization. Even some of Mayo's own

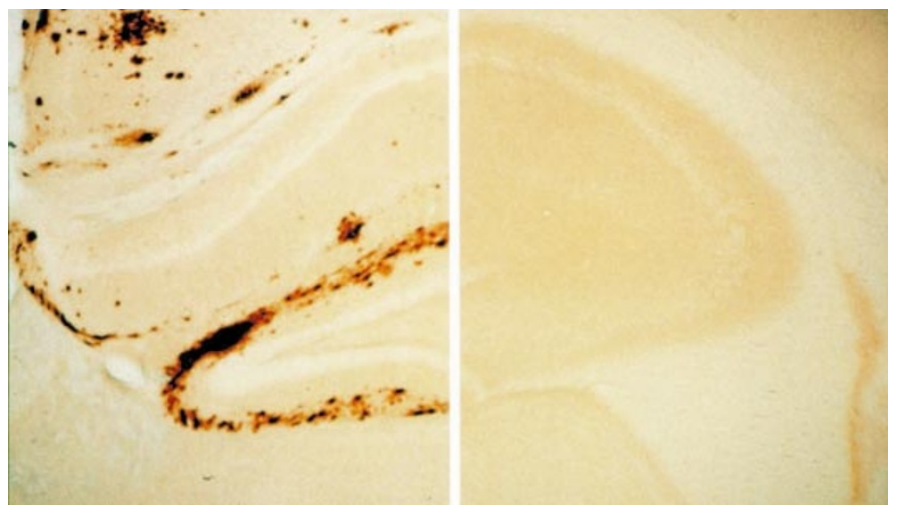

Mice work: the brain of Elan's one-year-old mouse (far left) shows characteristic plaques of Alzheimer's disease, absent from that of the similar animal (left), which was dosed with Elan's experimental Alzheimer's vaccine.

researchers have difficulty with this practice.

"My view is there should be no reachthrough agreements between non-profit institutes," says pharmacology professor John Hardy at Mayo's Jacksonville facility, whose laboratories at Imperial College London, South Florida and Mayo have produced leading discoveries and researchers.

But Steven Younkin, a physician neuroscientist and former director of research at Mayo's Jacksonville facility, defends the agreements as being necessary to cover the organization's enormous cost for the longterm, mouse-producing project. "With a non-profit institution such as Mayo, any money realized from licensing agreements goes back into research," says Younkin.

If Mayo was primarily interested in making money, he adds, it would have entered an exclusive licensing agreement for the transgenic mice with a single pharmaceutical firm. It deliberately decided not to do this, in order to make the mice available for academic research.

As neuroscientists debate these issues, subpoenas have been spreading through the neuroscience community. Earlier this month, Elan failed in a bid to require Hsiao to produce her laboratory notebooks for a deposition this week.

A number of researchers, including microbiologist David Borchelt, an associate professor of pathology at Johns Hopkins University in Maryland, are debating their options as they face subpoenas. Unable to secure the desired transgenic mice, Borchelt made his own mice.

Elan has now subpoenaed him and his lab notebooks, which he fears may be studied closely by the firm's scientists. Borchelt says he would "go to jail" rather than provide his notebooks. Rex Dalton

\section{Computer glitch unleashes prize nomination debate}

Boston

The normally tranquil world of statistical physics and mechanics was rocked last week by a computer glitch that led to a flurry of exchanges over nominations for the field's most prestigious prize, the Boltzmann Medal. The prize is awarded by the International Union of Pure and Applied Physics (IUPAP) once every three years.

The glitch triggered a debate between those who regarded the proliferating e-mail messages as a nuisance that threatened to overwhelm computer networks, and others who welcomed an unaccustomed openness.

The source of the problem was the 3,500strong mailing list kept by the Center for Mathematical Sciences Research at Rutgers University, which hosts two conferences on statistical mechanics each year.

Kurt Binder of the University of Mainz in Germany, who chairs the IUPAP committee that issues the Boltzmann Medal, asked Joel Lebowitz - a member of the nominating committee - to send an announcement soliciting nominations. (The next prize will be awarded in Mexico, in summer 2001.) Recipients were meant to reply to him alone, not sending their comments to each other.

Juerg Froehlich of Eidgenössische Technische Hochschule Zurich nominated John Cardy of Oxford University, also citing the work of Sasha Zamolodchikov of Rutgers. "But something went wrong," says Lebowitz. "The computer went haywire" when Froehlich hit the 'reply' button, and his suggestions went to all 3,500 on the list. Others soon joined in the nomination frenzy. Roger Bidaux of the Centre d'Etudes de Saclay in France advanced the name of Lawrence Schulman, a physicist at Clarkson University in Potsdam, New York. "I believe that our community can afford a little bit of tolerance and democracy, and allow me to express my opinion," wrote Bidaux.

University of Rochester physicist Yonathan Shapir shared this sentiment, saying he'd like to see the process conducted in a more open, democratic fashion.

"There is a lot of secrecy in academia," says Shapir. "I don't like the way this business is handled, with just a few people making decisions for the rest of us." The Internet, he adds, "could allow us to hold large 'town meetings,' where many people voice their opinions and, in the end, a vote is taken".

Several respondents, though, argued that nominations should not be aired in public.

Meanwhile, Haym Benaroya of Rutgers was anxious to avert an e-mail meltdown, and urged people to stop sending messages to the Rutgers list. "At one point, I was getting 10 to 15 e-mails every 10 minutes," he says. "With everybody talking to everybody else, things were snowballing. The whole system could have been shut down."

The snafu was corrected within a day, and an apology issued. Future nominations were requested by post, rather than e-mail.

The apology put an official end to the episode. But Shapir hopes that an important lesson might still be learned. As a result of the computer glitch, he says, "for a brief period of time, we got a glimpse of how things could be done. We don't have to cling to the secretive ways of the past." Steve Nadis 